\title{
Supply Chain Analysis of Tourism Social Enterprises in Bejiharjo Tourism Village
}

\author{
Antonius Budisusila, JJ Sarungu, Vincent Hadi Wiyono, A.M. Soesilo
}

\begin{abstract}
Bejiharjo Tourism Village was established as a tourist destination in 2010. The development of CBTIs as a form of community social enterprise is considered important because the company is expected to foster economic, socio-cultural and environmental harmonization. Development of tourist destinations in the village of Bejiharjo is the opposite. Based on an analysis of the performance of tourist supply chain (TSC) management, the level of citizen participation, the number of tourists, and tourism income increased dramatically in the beginning of the growth. However, in recent developments, the level of participation is no longer in line with the number of tourist visits and income. In fact, social companies operate on limited, inefficient management performance, poor tourism services, and tourist disaffection. This is due to the weakness of social companies in managing TSC. The company faces various scarcities and weaknesses in developing strategies and management of each chain. This can be seen from the weak source of empowerment strategy, enterprise management, development and innovation of tourism products and tourist services. Government policies tend to be ineffective, have unclear rules, and are accompanied by difficulties in establishing rules and agreements between companies. The entire process of TSC management has made social companies face conflict among enterprise and landlord and the performance fell sharply. Furthermore, this condition might marginalize and disadvantage the destination. This is a big challenge for the process and purpose of the community social enterprises.
\end{abstract}

Index Terms: Supply chain, Social Enterprise

\section{INTRODUCTION}

Tourism is regarded as this century's most strategic sector as it has the ability to improve the community's prosperity in various dimensions and its deployability in different walks of life[1] as well as urban and rural societies [2]. It becomes one of the fastest growing economic sectors globally[2],[3] and it is able to increase development distribution and parity as well as reduce excessive natural resources use and exploration[4].

Specific to tourist destination development, the most popular initiative used is the community-based tourism initiatives (CBTIs). It is a development strategy that places

Revised Manuscript Received on September 22, 2019.

Antonius Budisusila, Sanata Dharma University, Faculty of Economics, Yogyakarta Special Region, Indonesia, 62-274-562-383, :abudisusila@gmail.com

JJ Sarungu, Sebelas Maret State University, Faculty of Economics and Business, Surakarta-Central Java, Indonesia

Vincent Hadi Wiyono, Sebelas Maret State University, Faculty of Economics and Business, Surakarta-Central Java, Indonesia

A.M. Soesilo, Sebelas Maret State University, Faculty of Economics and Business, Surakarta-Central Java, Indonesia local communities as a destination's "host" and management[5]. This strategy is expected to create development equity in social, cultural, economic, and environmental dimensions.

Studies on CBTIs have shown a number of successes. To their proponents, CBTIs are panacea for curing social, economic, and environmental problems [6]. The participation and commitment of local communities are a fundamental prerequisite for sustainable tourism [7, 8]. Community-based tourism is deemed to be a savior for local economic crises[9]. This model also has a positive impact on small and medium enterprises development as it can develop local knowledge systems[10] and reinforce social capital, network, and social norms that constitute paramount factor in explaining communities' collective action involvement, and this collective action will make the communities better[11].

On the other hand, separate studies has shown community-based tourism initiatives' failures. CBTIs possess just the same potential to stir social tensions, discords, conflicts, and even disputes in the "host" communities[12]. In the tourism development in Chinese rural areas, conflicts primarily came from land confiscation, ticket income distribution, torusim management rights, demolition of houses, construction of houses, entry restriction, and village selection[13]. The management of ancient town (Machu Michu) has debilited the town's protection and roused cultural tensions within the communities[5]. A study in South Africa on Logindo's CBTIs management also demonstrated non-transformative development causing local communities' over-reliance upon donors[7]

The studies of CBTIs have been inclined more to using and presenting social, cultural, and political perspectives. It can be understood, because of the scarcity of resources and institutions owned by "the host" (such as: weak authority, access, institutional and human resource capacity). However, it caused the dearth of CBTIs perspectives as corporate organizational entities. As an organizational approach, CBTIs are type of social enterprise [15]. Not only social goals, social enterprise also stresses on the production process of goods and services and the participation of all stakeholders-volunteers, employees, managers, users, representatives of public and private entities-in its life, which is not easy[16]. 
This study focused on the use of tourism supply chain management (TSCM) perspective for social enterprise. The TSCM study of CBTIs is not common. In any case, the heart of community-based tourism initiatives as an enterprise is the chain of governance, management, and business performance. Governance relates to the processes of interaction and decision-making among the actors involved in a collective problem that lead to the creation, reinforcement, or reproduction of social norms and institutions[17]. Tourism management is industry in which different products/services are bundled together to form a tourism product[18]. Tourism supply chain with regard to social enterprise - has been ever more necessary.

The use of SE supply chain gives novel perspective on CBTIs. This approach offers development of knowledge on tourism supply chain management in community social enterprises (CSE). The pratical implications of this study include the potential and policies relating to more professional social enterprise reinforcements, increased cooperation between supply chains, and enterprise's efficiency and competitiveness in achieving the goals of CSE.

\section{LITERATURE REVIEW}

\section{A. Cbtis As Social Enterprise}

\section{1) CBTIs}

CBTIs is deemed to be of importance as it holds normative, democratic, and inclusive principles. Normative aspects are found in the following respects: cooperation and emphasis on concensus, environment, or ecology; human rights; community locality and values; prosperity and social justice; and process of and concern on local and global connectedness [19]. The democratic principle of CBTIs places development strategies bottom up. In inclusives principle, every citizen has the right to participate, right to access resources and properties, and authority to conceive and make decisions regarding governance and structure of community organisation [17].

CBTIs allow opportunities to empower local communities, especially those in developing countries, to develop better sustainable tourism from grassroot than mass tourism does; to contribute to local economic development and poverty alleviation[20]. This tourism development model is a community initiative to plan development that encompasses masterplan, assessment or inventory of elements of the tourism system, and checking the presence of web and community information technologies in participative and inclusive manner.

\section{2) CBTIs as Social Enterprise}

Social enterprises (SE) aim to achieve common welfare of community members (bonnum commune) in the sense of public welfare. It links economy, social responsibility, and environment. Social enterprise as an entrepreneurial organization strives for social goals and succeeds on the account of its members' non-egoistical motives. [15] asserts: "SE is organization that applies commercial strategies to maximize improvements in financial, social and environmental well-being - this may include maximizing social impact alongside profits for external shareholders".

The definition and key features of SE have been developed since the introduction of the enteprise law by Britain in 2004[21] and Italy in 2005[22]. The organizational feature and type of SE is dissimilar to neither public nor private companies. [23] described it as "a place of social-economy" (Figure 1.) as in his statement:

social economy is described as an entrepreneurial, not-for-profit sector that seeks to enhance the social, economic and environmental conditions of communities. The term is often confused with social market economy. While similar in name, they refer to two quite different political and economic concepts. Social economy is used to define a specific part of the economy that works alongside the market and the state: a set of organizations that primarily pursue social aims and are characterized by participative governance systems.

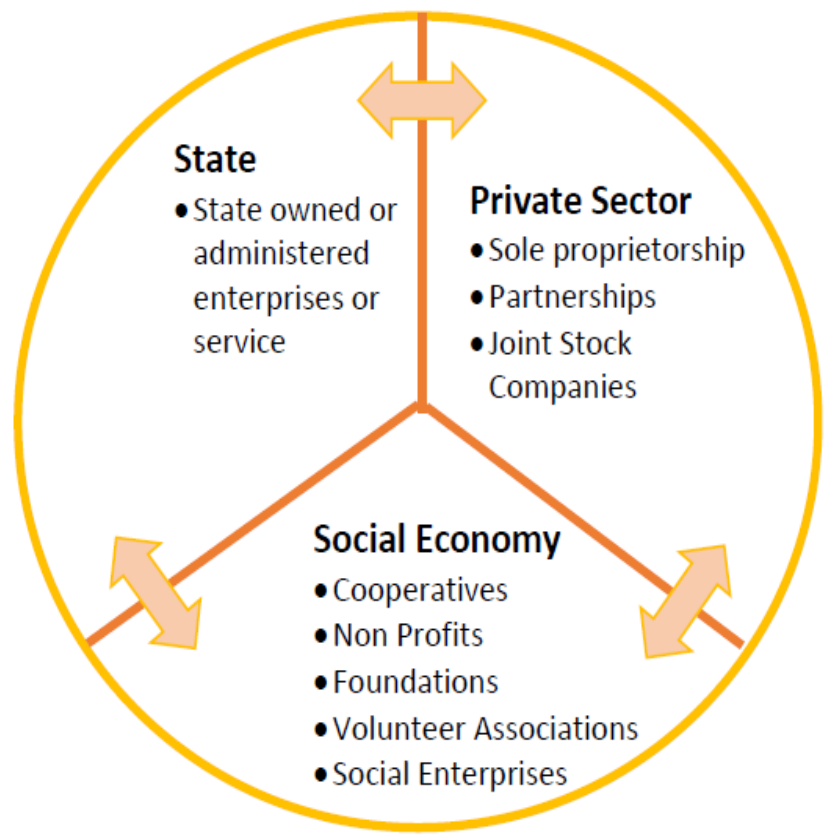

Fig 1. A Place of Social Economy[23]

The type of SE may be arranged as hibryd organisation[24]. The enterprise may take various forms, depending on which country, domiciled and the legal form available. Some of the existing forms include cooperatives, mutual organization, disregarded entity, social business, foundation, association, or company limited by guarantee or some sort of charity organization. SE may be productive when for-profit company and public agent are no longer effective, unable to operate responsibly. Based on the innovation model employed and the governance form, SE may produce public or semi-public goods (i.e., goods and services that have common/collective benefits, be useful for the wider community). Hybrid organizational is usually deemed more efficient, innovative, and productive than public institutions or profit company models. 
This is especially true as the market and contract imperfections, asymmetrical information, high relational intensity in goods/services production, also tinge the business climate in the community

\section{B. Supply Chain Management}

Supply chain management (SCM) is commonly used for manufacturing industries rather than the tourism industry. The principal difference between the supply chain of tourism products and that of other products lies in the fact that customers travel to where the products are consumed and the products themselves are made of wider services. Thus, the actors play a considerably significant role in this case since they provide the services in a direct fashion[25].

Furthermore, [25] defined tourism supply chain (TSC) as a chain that covers the suppliers of all goods and services who are involved in the provision of tourism products for customers or visitors. [18] took into account the specificity of TSC as a network of organizations engaged in the tourism sector that provide myriad partial tourism products and services used for making and then distributing ready-to-use tourism products at tourism destinations. Irrespective of the definitions of TSC quoted previously, it is worth keeping in mind that they do not emphasize customers as the final chain. The expectation and demand of costumers, play vital role in creating new chain. [26] and [27] suggest when analyzing of TSC, the following elements should be considered: the structure (strategies, concepts, distribution channels, competitive edges, etc.); market-individual relation (e.g., between culinary units, accommodation facilities, travel agents, and tourists); and chain performance measurement (tourist satisfaction, financial performance, operational efficiency).

[28] explain six characteristics of tourism chain management: industry where different goods/services are bundled together to form finished tourism product, requiring intensive coordination; the services are not storable for future use (non-perishable), tourism product consumption, tourists should go on a travel to the destinations where the tourism products are produced. Therefore, tourism industry is information-intensive or information-dependent industry with highly complex products that are normally heterogenous and composed of a wide range of service components (e.g., accommodation, transportation, traveling, cuisine, and shopping). Tourism industry is often faced with high demand uncertainty, while tourism has dynamics with greater complexity due to the intensity of competition between service providers. Many entities with differing TSC participate in the process of creating and distributing tourism products.

\section{Supply Chain Performance}

The inherent complexity of TSC needs to select the right and effective performance measures. Regardless of the immense body of literature on the measurement of manufacturing supply chain performance, little attention has been given to such measurement in SE and tourism industry. The chief objective of performance measurement is to make certain that an organization and all of its subsystems (process, department, team, employees, etc.) work together optimally to achieve the organization's desired outcomes.

Table 1. Performance Measures of Supply Chain Analysis

\begin{tabular}{|c|c|c|}
\hline $\begin{array}{r}\text { Financial } \\
\text { Performance }\end{array}$ & $\begin{array}{l}\text { Operational } \\
\text { Performance }\end{array}$ & \begin{tabular}{|r} 
Overall \\
Supply Chain \\
Performance
\end{tabular} \\
\hline $\begin{array}{l}\text { - } \text { Total Cost } \\
\text { - } \text { Distribution } \\
\text { Cost } \\
\text { - Manufacturing } \\
\text { Cost } \\
\text { - Inventory Cost } \\
\text { - Return on } \\
\text { - Investment } \\
\text { - Total Revenue } \\
\text { - Profit }\end{array}$ & $\begin{array}{c}\bullet \text { Customer } \\
\text { Response Time } \\
\bullet \text { Manufactu } \\
\text { ring lead Time } \\
\bullet \text { Product } \\
\text { Quality } \\
\bullet \text { Product } \\
\text { Availability }\end{array}$ & $\begin{array}{l}\text { - } \text { Costumer } \\
\text { Satisfaction } \\
\text { - Supply Chain } \\
\text { Flexibility }\end{array}$ \\
\hline
\end{tabular}

Sumber: [18]

The performance measures used in the TSC analysis can be categorized into monetary and non-monetary measures. Supply chain related to coordination, collaboration, cooperation, and working together processes, internally or externally. The TSC process is not easy when it is measured through money value owing to its qualitative nature. The performance and outcomes of CSE tend to be diverse and complex, for example: tourist satisfaction, financial performance, operational efficiency ([18], Table 1.) as well as other measures that display the results of sustainable tourism development in the community[4].

\section{RESEARCH METHODS}

This research is qualitative research. Research data were obtained through in-depth interviews with all managers of tourism SE in Bejiharjo Village. It is expected that the research can answer all of the research questions. Twelve (12) managers were interviewed for this purpose. This study also used secondary data, such as records, documents, webs, and reports of the company to supplement the primary data. Overall, the data were analyzed using a qualitative approach.

\section{RESULTS AND FINDINGS}

\section{A. Bejiharjo Village as a Case}

Bejiharjo Village is one of villages in Indonesia. This village is situated in Karangmojo District, Gunungkidul Regency, Yogyakarta Province. It is also situated in the same location as Gunung Sewu Karst, which is acknowledged as world heritage by the UNESCO.

As a community-based tourist destination, it has many tourism resources in terms of nature, history, and culture. First, the village has diverse and appealing natural riches of a karst. 
The most karst areas are found in dry, barren areas, while this village is blessed with abundant water resources. In terms of quantity, this village has at least 20 caves that are open for exploration as tourist objects. Second, this village hosts various sites, fossils, artefacts, pre-historic objects (from the megalithic age), objects from ancient kingdoms, monuments from the colonial era or pre-independence era, and objects from the post-independece day. These are historical assets that have existed since as far back as the megalithic era. Third, this village also has various local cultures which tourists can enjoy, such as dancing, wayang (puppet), traditional music, visual, and craft arts. As it happens, the culture is also present in the community's life events, for example, in bersih sumber ceremony aimed for conserving water resources as well as other ceremonies like naming, wedding, and death ceremonies.

Forth, different livelihood sources for its residents that support its development as a tourist destination can also be found here, for instance: agrotourism like sacred forest, eucalyptus forest, fishery, animal husbandry, ricefield, among others. It also runs agricultural product processing industry, for example, eucalyptus oil, bamboo crafts, bags, blankon (Javanese traditional cap).

\section{B. Community Social Enterprises}

1) Pokdarwis as Social Enterprise

Tourism development in this village began in 2010. As fully participative enterprise, pokdarwis, or kelompok sadar wisata (tourism awareness group), is an institutional, governance, and organizational structure that was introduced to manage local tourism and tourist destinations. It has been authorized by the government through some village and local government regulations. The first regulation is Regulation No. 15/KPTS/2010, dated June 30, 2010 on the Establishment of "Dewa Bejo" Tourism Awareness Group. This was later backed up by Regulation of the Gunungkidul Regent No. 98/KPTS/TIM/2015, dated April 11, 2015.

In the aforementioned regulations as well as the planning and establishment documents of pokdarwis, it is clearly stated that Pokdarwis Dewa Bejo is community-managed social enterprise. Community organization aims to accommodate potentials collectively for the welfare of its members and the local community (Article 5). Article 6 also states that Pokdarwis has the form and properties of an association that plays role in strengthening unity; raising awareness among community members; pioneering the development of various tourism potentials in the immediate neighborhood or at the village level; and conserving the art, cultural, adat (custom), and historical values that support the advances in the tourism sector and has positive impacts economically, environmentally and socially on the community.

\section{2) Enterprises and Tourism Objects}

This tourist village experienced rapid growth in the number of social companies increasing during development. There is an average of 1-2 new enterprises emerging every year (Figure 2.). The increasing number of visits and many natural tourism potentials in the village drive the community to build enterprises as a form of community participation. Such enteprises are founded by elite community figures, and they employ the people who reside near the enterprises. There were up to 12 tourism enterprises in the study village until 2018.

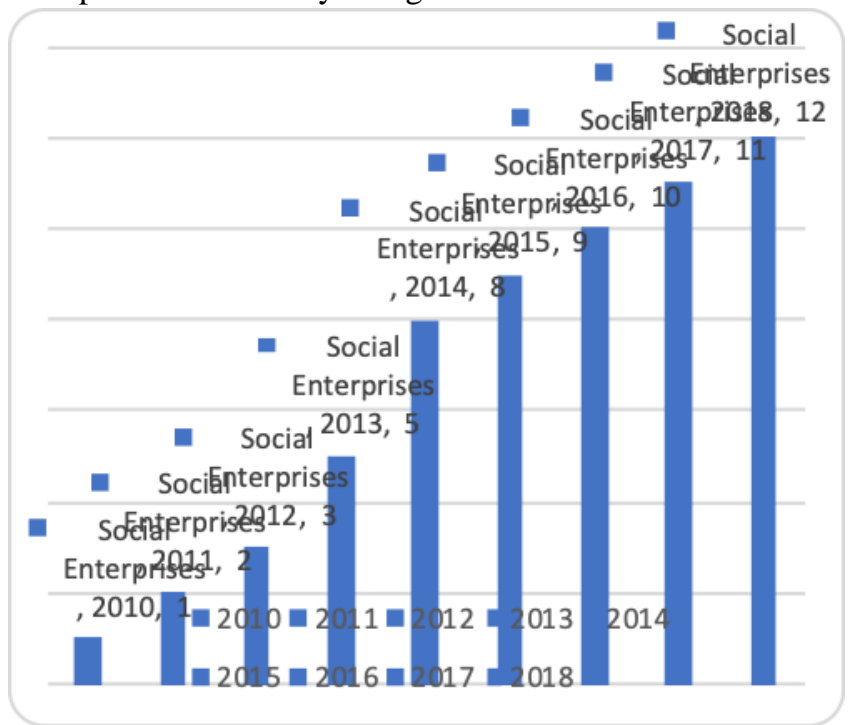

Fig 2. Number of Social Enterprises (Unit)

The development of SE led to the issuance of government policy for regulating destination management. The policy is known as "One Destination, One Management" (ODOM). Four tourism enterprises have been managing the destination of Pindul Cave. The four enterprises are destination developer start-ups. The enterprises'growth is covered in the government regulation scheme on the basis of territorial sub-village, hamlet authority and the road toward the entry of the destination Pindul Cave. Since Pindul Cave is situated at the meeting point of four hamlets, the tenure right of Pindul Cave falls to them. Other enterprises manage other tourist objects (Sriti Cave, Tanding Cave, Oya River rafting, off-roading, etc.). All of the enterprises have tourism objects, but SE do not develop their objects adequately. Pindul Cave is just the first and final tourist object developed as flagship product in this village. The tourism activity offered by the enterprises was cave tour.

\section{The Supply Chain Performance}

\section{1) Community's Level of Participation}

The community enterprises are the main form of community participation. The enterprises were managed by 120 people holding the positions of advisors, managers, and field managers. They were able to employ 889 people as guides, social media administrators, sanitation officers, or cave tour equipment officers. The enterprises had hired 1,019 people. The community's level of participation in these tourism enterprises reached $6.36 \%$ of the total population (Figur 3.).

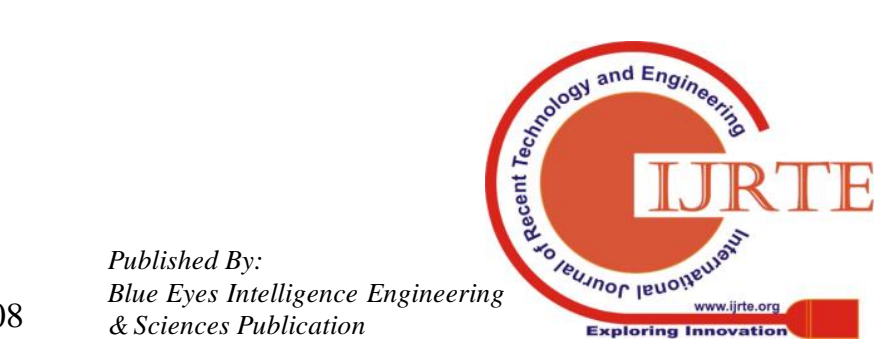




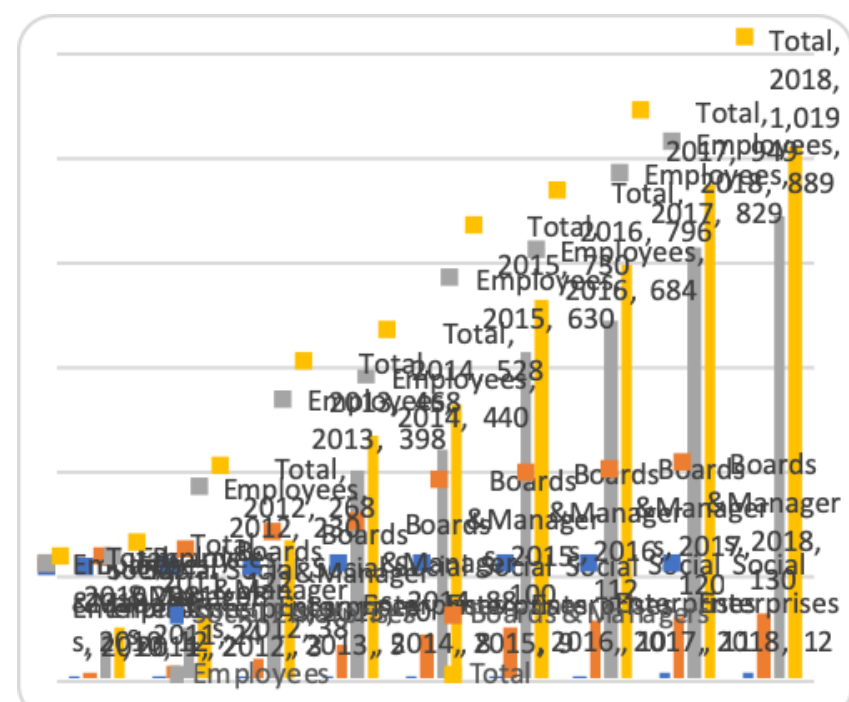

Fig 3. Number of Social Enterprises (Unit), Boards \& Managers, and Employees Hired (in People)

With the growth of the number of the enterprises, people living in the vicinity of the enterprises offices also enjoyed the opportunities of running souvenir outlets, food courts/catering businesses, and homestays (Figure 3.). These were home businesses that engaged employees from their households. Over the eight years' period, there had been 18 operating homestays, while the number of workers involved in these businesses was 42. All of the workers worked in self-owned lodging businesses. Culinary businesses occupy enterprise-provided premises (provided by the enterprises by means of renting) or restaurants that shared location with the owners' dwellings. As many as 92 units of culinary and souvenir business had been operating, and they had employed 253 workers in 2018.

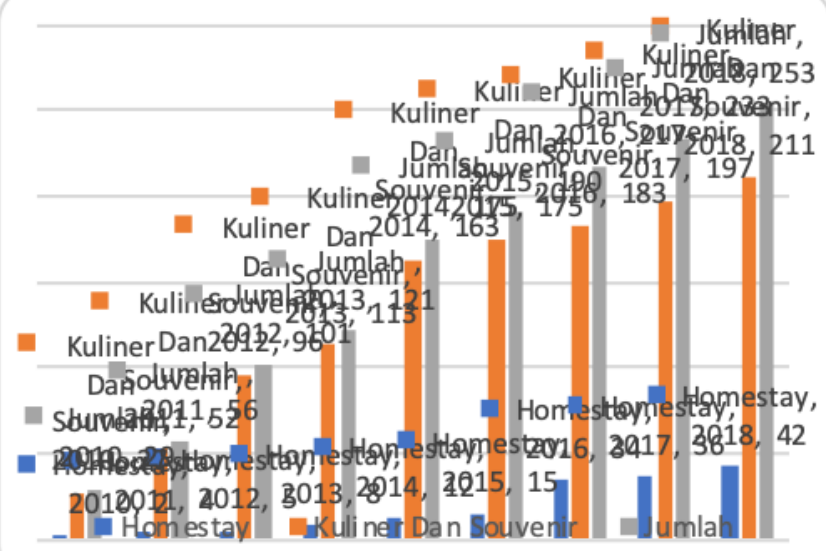

Fig 4. The Number of Workers Involved in Culinary and Homestay Businesses (in People)

The number of people relying their lives on the tourism sector has been swallowing. The people working in the homestay, culinary, and souvenir businesses had numbered 253. The community's level of participation in the complementary nature-, history-, and culture-based businesses was estimated to make up $1.65 \%$ of the population. The overall percentage of community's participation was $8.01 \%$. These figures did not include the community's informal participation, such as hawking, brokery, etc. If such informal participation is included, the participation would reach $10 \%-12 \%$.

\section{2) Tourist Visits and Value}

Some other vital measures of performance are the number of visits and visit value. Early in the eight years' period, the number of visits escalated sharply. This occurred from 2010 through 2016. The stages of exploration, participation, development, and consolidation were passed by the existing CSE in a short period of time, and the stages of stagnation and decline soon followed (Figure 5.).

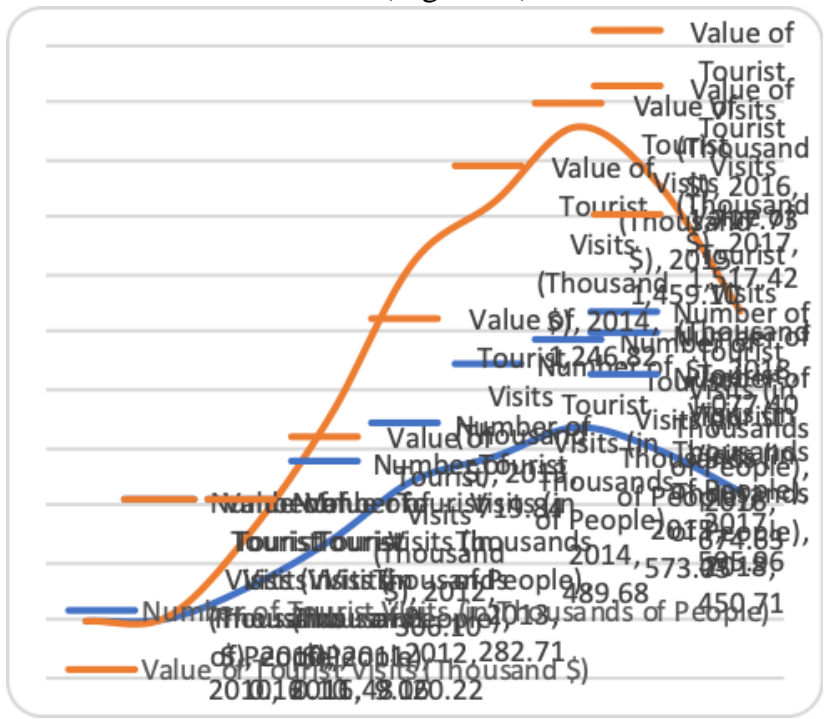

Fig 5. Number of Visits (in People) and Visit Value (in thousands of US dollars)

The downturn started from 2016. This is in actuality a normal phenomenon, especially with the number of visits remaining relatively high. However, this decrease had roused varied perseptions for the CSE. Such perseptions had also steered their strategies in facing the competition between local enterprises.

\section{3) Falling Financial Performance}

Figure 5 also shows that the visit value had dropped, even more dramatically than the drop in the number of tourits. This was marked by visit value slope steeper than that

of the number of visits. Visit value was measured based on the number of tickets sold and the ticket purchase price. Why did the number of visits not go with the visit value despite the purchase price set? The growing number of SE had caused the competition between them to grow to be all the more intese. This competition intensity more often than not made the CSE "less self-appreciative", more eager to win the competition, and lack the willingness to cooperate with each other. They sold the tickets cheaper than the price agreed. Amidst such fall and price war, with one enterprise attempting to tackle another, the financial performance of the enterprises also slumped. These enterprises were even at high risk of "sudden death".

\section{4) Tourist Satisfaction}

The rapidly increased number of visits lowered the quality of the tourist services. Reports on print and online media have indicated this since 2015 . There have been long lines before the mouth of the cave, indicative of over-visits. 
These media are critical to the management of Pindul Cave. One tourism-focused online reporting once wrote, "Wisatawan menyemut di Goa Pindul" (Tourists infest Pindul Cave). This title gave the impression of inhuman treatment for tourists (Figure 6).

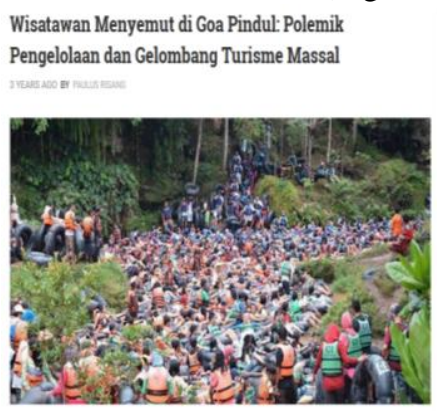

Source: [29]

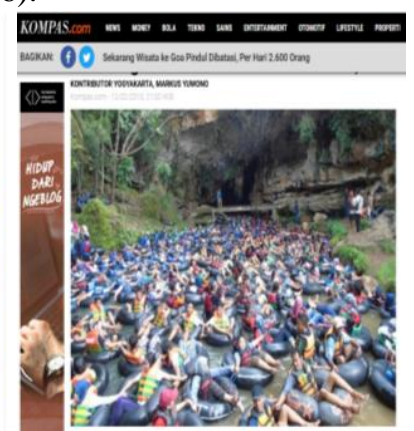

Source: [30]
Fig 6. Pindul Cave Tourists: Human or Cendol?

Twitter account @tri_handayani, once viral, posted the same photo on social media and commented, "Bullshit....ini manusia apa cendol[31]?" (Bullshit....are they humans or cendol?). This comment had sarcastic tone in that it regarded tourists as undistinguishable from objects or that tourists were preys to SE. There were a lot of dissatisfied commentaries as well. Tourists felt that they did not receive decent service from 2015 through 2018.

\section{Enterprise Supply Chain Complexity}

\section{1) CSE Supply Chain}

Based on the supply chain model applied in the community, SE had series of supply chain links and interconnection between actors. The CSE confronted a number of descrete parts, but complementary to one another, in forming tourism products (Figure 8.). First, they encountered ownership regimes of resources (nature, culture, and history), community members, and their tourism-supporting livelihoods (agriculture, industry, housing, etc.). The entire consolidation and resourcing processes were based on the mutual benefit principle. The second is the amenity provision in the community. All of CSE preferred to be segregated from the amenity service unit or units of other supporting services such as accommodation, culinary, sanitary and souvenir. This was aimed to give a room for the community's participation so as to prevent the enterprises from dominating the tourism revenues.Third, the SE were also faced with options of models and forms of community's participation. This was related to the attempt to determine their ownership among stakeholders. They could engage some, all, or none of the ownership. When there was no engagement, community participation could be translated as the employment of local people as workers in the enterprises. This would determine the enterprises' "governance mode" and governance structure at the each enterprises.

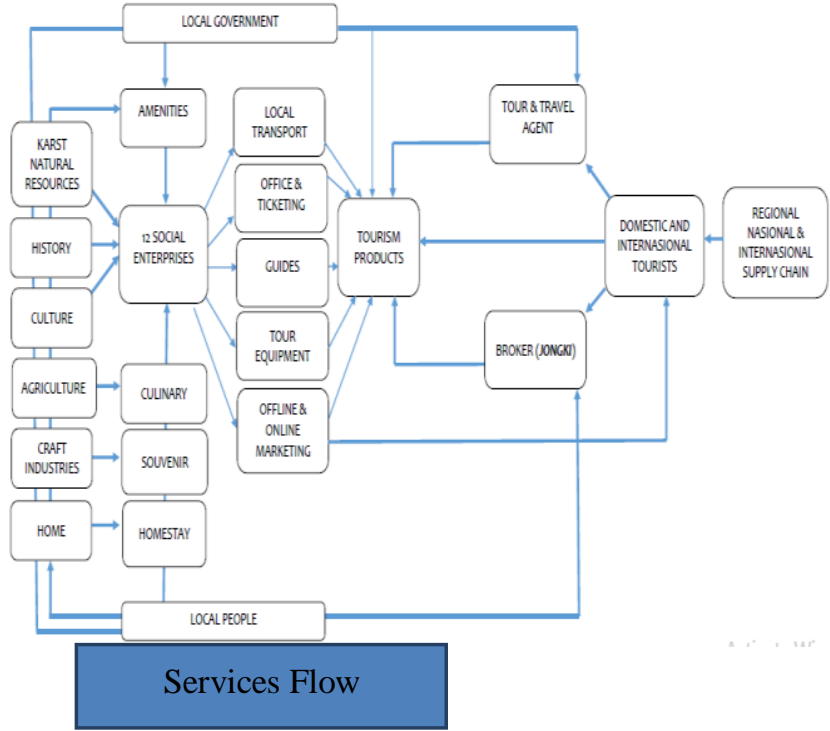

Fig 8. Tourism Supply Chain at in Bejiharjo Village

The fourth was creating and specifying tourism service products. This would require sound cooperation between parties as elements of the tourism supply chain that benefited the enterprises' organizations. The fifth was the local government's role in creating and protecting the tourism business climate. The local government had the functions of facilitation and conference of resource management authority to the community in relation to community-based tourism services.

The sixth was regional, national, and international supply chain. The facilities and infrastructures available included transportation (airport, port, terminal, etc.), access (adequate main roads and destination roads), and accommodation (hotels, lodgings, guesthouses, etc.) All of the aforementioned aspects were external factors important for the SE to improve the number of visits to Bejiharjo Village.

\section{E. Why did the Performance Drop?}

The SE had failed to maintain their operational efficiency, financial position, tourist satisfaction, and sustainability. How could this happen? This is related to a number of problems that arose in every TSC link. The problems are elaborated below.

\section{1) Resourcing Link}

\section{a) Property right uncertainty.}

Uncertainty of the rights to the underground rivers and cave karst ownership, giving all of the people the claim on the access to the resources. Conflicts and disputes over the tourism resources marred during the destination development. Local governments and SE had to be faced by the claims filed by landlords (owners of large lands) due to such uncertainty. 
b) Participation without empowerment.

Early in the development, the community's participation had to start from empowerment, training, and education by government agencies and universities. The guiding position was open to everyone as long as they were interested without empowerment. The community's participation tended to be uncontrolled, and the enterprises had to bear the growing employment burden.

\section{c) Marginalization of history, culture, and} agriculture.

The nature tourism was not integrated with the historical, cultural, and complementary sectors. According to the enterprises' work plan, the tourism business was aimed to conserve the culture and history of the local community. However, in practice, there was no cooperation or relation with local cultural and historical actors. There was a lack of adequate integration with supporting sectors, which led to "uncertainty of benefits from tourist visits" for those sectors. As result, the cultural products did not receive any benefit from tourism, and even became marginalized from tourism. This was also the case with other supporting sectors. Some sectors obtained more benefits, for example, culinary, homestay, and souvenir sectors, but some others, like agricultural one, had no other choice but facing "workforce scarcity" and increased wage for the workers.

\section{2) Resource Management Link}

a) Elite domination.

The enterprises' ownership is in the form of cooperative and association, but the executives dominated the decisions and tourism revenues. There was a wide gap between the management and the employees.

\section{b) Weak managerial capacity.}

The people's habits in managing their previous businesses were adopted when they were managing their tourism businesses. Managers call it "meatball management"; what they earned that day would be spent on the every same day.

c) Imperfect installement of community information and e-marketing technologies.

Marketing unit was the main attractor to tourists. The employees' ability to design the e-marketing did not receive due appreciation. They received the same amount of wage as that received by other employees. Most of the managers were of the "baby boomer" generation and were not familiar with information technologies, while IT emplyoees were of the millennial generation. This gave IT employees' critical role in the marketing. They even exerted their influence outside the enterprises and determined the value of transaction between tourists and the enterprises

\section{3) Tourism Product Development Link}

Focusing on one product or tourist destination.

Many interesting destinations were hosted in Bejiharjo
Village, but all of the existing enterprises relied only on the attraction of Pindul Cave. There were many innovative attractions developed by startup social enterprises, namely limited innovations in the early stage of the development like off-roading and rafting at Oya River.

\section{a) Limited product development innovations.}

Every social enterprise operated in its own destination territory. However, they did not innovate their products even in the tourist objects they managed on their own. This was consistent with their weak managerial capacity that caused them to have inadequate financing for making innovations as their income was spent for the management and employees.

\section{4) Market and Distribution Link}

\section{a) Liberal competition between enterprises.}

Enterprises competed over the authority to manage the destination and main tourism products. The organizational structures were homogeneous. All of the enterprises had the same structures, where they "copied" the already-operating structure. Consequently, the enterprises lacked "competitive edges". Liberal competition among SE causes the lack of coordination and cooperation mechanism between enterprises, the difficulty in arranging joint agreements and consensus.

\section{b) Declining tourist satisfaction.}

The enterprises were also overwhelmed by tourist explosion in the beginning. The toursits were interested to walk along the river in Pindul Cave. This huge interest induced a rise in the number of visits, and consequently, long queues of those who wanted to visit Pindul Cave. These long queues made the employees, travel guides, and tourists engaged in dramas of social conflicts: some tourists cutting the line, spontaneous arguments, and swearing between employees in front of the queuing tourists. These behaviors had disinterested and dissatisfied the tourists.

\section{c) Brokers' domination in the market.}

Jongki, or brokers, were the middlemen engaged in the tourism sector. They offered facilitation for the tourists' visit. They supplied tourists by negotiating the price set by the enterprises then offered to the tourists at higher price. This put both the tourists and the enterprises at disadvantage.

\section{5) Policy and Rule Enforcement Link}

\section{a) Weak local leadership.}

The village government tended to "stand back" more and be "indifferent". They did not regulate nor manage the enterprises growing in the community. They shifted the responsibility to the upper local governments. 
b)

Ineffective Government Policy.

This policy was unable to compel the SE to manage their objects.

\section{c) Weak rule enforcement.}

The government was unable to enforce the rules for the competition between SE or prevent the emergence of informal actors like brokers. Brokers could potentially harm both the enterprises and tourists, but to date, there has been no firm measures applied to them.

\section{CONCLUSIONS AND RECOMMENDATIONS}

\section{A. Conclusions}

CBTIs as type of SE are deemed important as they carry normative, democratic, and inclusive principles with them. SE'objectives are to build harmony between economy, socioculture, and environment in the community. What happened in the tourist destination development in Bejiharjo Village was just the opposite. Based on the analysis of the tourism supply chain management, a high number of visits were not sufficient to ensure that SE would yield favorable performance, be efficient, provide excellent tourism services, and brought satisfaction to customers.

This happened due to the SE' weak supply chain management. The enterprises faced various drawbacks in the resourcing link, enterprise management, and tourism product development and innovation. Even inefficient policing and weak rule enforcement by the government had caused the SE to see a slump. Worse yet, this slump could potentially lead to marginalization of the historic, cultural, and environmental sectors and potensial end up with the death of the destination.

\section{B. Recommendations}

It is necessary for the CSE to formulate coordination and cooperation steps to deal with the weaknesses in the SCM. The government also holds an essential role in ensuring policies and rules related to rights to properties, tourism product development and innovations, destination rejuvenation, and integration between supporting sectors. This study does not elaborate on the supply chain and dominant elements making up the degeneration in the SE' performance. Thus, this study should be followed up with further measurements and proximate analysis of every chain that potentially led to the performance degeneration of the enterprises.

\section{ACKNOWLEDGEMENT}

I am very grateful to the supervisor and co-supervisors, and also Sanata Dharma Foundation which has funded my dissertation research. This paper is part of dissertation on Tourism Destination Governance Arrangements: A Case Study of Bejiharjo Communty-Based Tourism in Karangmojo, Gunungkidul, Yogyakarta Special Region, Indonesia.

\section{REFERENCES}

[1] Bramwell, B. 2011. Governance, the state and sustainable tourism: a political economy approach. Journal of Sustainable Tourism, 19(4-5): p. 459-477.

[2] Habito, H.V.J.2013.Community Development through Tourism: Opportunities and Challenges in Burdeos, Philippines, in Tourism and Leasure Study. Dissertation, The Hong Kong Polytechnic University School of Hotel and Tourism: Hongkong.

[3] UNWTO, 2016. UNWTO Annual Report 2015, UNWTO: Madrid.

[4] Polnyotee, M. and S. Thadaniti, 2015. Community-Based Tourism: A Strategy for Sustainable Tourism Development of Patong Beach, Phuket Island, Thailand. Asian Social Science; Vol.11(No.27, 2015).

[5] Sebele, L.S.2010. Community-based tourism ventures, benefits and challenges: Khama Rhino Sanctuary Trust, Central District, Botswana. Tourism Management 2010. 31(2010): p. 136-146.

[6] King, E. 2013. A Critical Review of Community-driven Development Programmes in Conflict-affected Contexts. London: DFID / International Rescue Committee.

[7] Stevens, M.A.2014. The Empowerment Paradox: Hope and Helplessness nn A Tanzanian Community-Based Cultural Tourism Initiative, in Faculty of the Graduate School. University of Maryland: College Park.

[8] Tosun, C.2005. Stages in the emergence of a participatory tourism development approach in the Developing World. Geoforum 2005. 36 (2005): p. 333-352.

[9] Gherco, A.V. and A. Trandafir,2014. Tourism Development in the Terms of Sustainable Development in Romania. Journal of Economics, Management and Financial Markets, 2014. Volume/Issue: Vol. 9(No. 1, March 2014).

[10] Manwa, H., 2012. Communities understanding of tourists and the tourismindustry: The Lesotho Highlands water project, African Journal of Business Management 2012. 6(22, 6 June, 2012): p. 6667-6674.

[11] Hwang, D.2012 Influence of Social Capital on Community-Based Actionin Tourism Development: A Study of Social Network Analysis, Dissertation in Departement of Recreation, Sport and Tourism. University of Illinois at Urbana-Champaign: Urbana, Illinois.

[12] Goodwin, H. and R. Santili,2009. Community-Based Tourism: A Success?, ICRT Occasional Paper, ICRT \& GTZ.: Leeds.

[13] Wang, L. and Y. Yotsumoto, 2019. Conflict in tourism development in rural China.Tourism Management, 2018. 70 (2019) p. 188-200.

[14] Pardy, H.M.H.W., 1999. Community entrepreneurship in north east Scotland, International Journal of Entrepreneurial Behavior \& Research, 1999. Vol. 5( Iss 4): p. $163-172$.

[15] 15. Mathew, P.M. 2008. Social Enterprises in the Competitive Era. Economic and Political Weekly, 2008. Vol. 43(No. 38 (Sep. 20 - 26, 2008)): p. 22-24.

[16] Young, D.R., 2012. The State of Theory and Research on Social Enterprises, in Social Enterprises-An Organizational Perspective, B.H. Gidron, Yeheskel Editor. 2012, Palgrave Macmillan: Hampshire RG21 6XS. p. 91-117.

[17] World Bank,2010. Results and Performance of the World Bank Group. World Bank: Washington.

[18] Zhang, X., Song Haiyan, and G.Q. Huang, 2009. Tourism supply chain management: A new research agenda. Tourism Management, 2009. 30(2009): p. 345-358.

[19] fe, J.2002. Community Development: Community-Based alternatives in an Age of Globalization, Frenchs Forest, N.S.W.: Pearson Education 2002.

[20] Kayat, K. and Zainuddin, N.F.A., 2016. Community-based Tourism Initiative in Rural Malaysia: Is It a Success? International Review of Management and Marketing, 2016( 6(S7) ): p. 242-249.

[21] Government of UK, 2005. The Companies (Audit, Investigations and Community Enterprise) Act of 2004 and the UK Community Interest Companies Regulation of 2005.

[22] Government of Italy, 2006. Italian Law 118/2005 on the Impresa Sociale and Ministerial Decree 155/2006. 2006.

[23] Grieco, C.2005 Assessing Social Impact of Social Enterprises Does One Size Really Fit All? 2015, London: SpringerBriefs in Business.

[24] Kerlin, J.A.2012. Defining Social Enterprise across Different Contexts: A Conceptual Framework Based on Institutional Factors, in Social Enterprises An Organizational Perspective, B. Gidron and Y. Hasenfeld, Editors. 2012, Palgrave Macmillan: London EC1N 8TS.

[25] Font, X., et al. 2008. Sustainable Supply Chain Management in Tourism. Business Strategy and the Environment, 2008. 17(2008): p. 260-271. 
[26] Muysinaliyev, A. and S. Aktamov, 2014. Supply chain management concepts: literature review. Journal of Business and Management 2014. 15(Issue 6 (Jan. 2014)): p. 60-66.

[27] Asir, M., et al., 2019. Study on Stakeholders Position and Role in Supply Chain of Cocoa Commodities. International Journal of Supply Chain Management, Vol. 8,(No.1, February 2019): p. 1-9.

[28] Song, Haiyan. 2012. Tourism Supply Chain Management. 2012, Abingdon, Oxon ; New York: Routledge, - Routledge advances in tourism. 202.

[29] Risang, P. 2015. Wisatawan Menyemut di Goa Pindul: Polemik Pengelolaan dan Gelombang Turisme Massal (Tourists Stem in Goa Pindul: Polemic of Management and Wave of Mass Tourism), in Hipwee media online, Tourism Publication Yogyakarta.

[30] Yuwono, M.2018. Sekarang Wisata ke Goa Pindul Dibatasi, Per Hari 2.600 Orang (Now Tourism to Goa Pindul is Limited, Per Day 2,600 People) in Kompas Daily. Jakarta: PT Gramedia

[31] @tri_handayani, Cendol or dawet is a traditional drink native to the Java Island, made from rice flour or glutinuous rice flour, served with shaved ice, melted brown sugar, and coconut milk. Tourists were compared with cendol that float in the mix of coconut milk, brown sugar, and ice., Researcher, Editor. 2016.

\section{AUTHORS PROFILE}

Antonius Budisusila affiliated with Sanata Dharma University, My area of interest is Economics, Yogyakarta Special Region, Indonesia

JJ Sarungu, ffiliated with Sebelas Maret State University, Faculty of Economics and Business, Surakarta-Central Java, Indonesia

Vincent Hadi Wiyono, affiliated with Sebelas Maret State University, Faculty of Economics and Business, Surakarta-Central Java, Indonesia

A.M. Soesilo, affiliated with Sebelas Maret State University, and my area of interest is Economics and Business, Surakarta-Central Java, Indonesia 